\title{
22
}

\section{ORGANISATIONAL KNOWLEDGE CREATION THEORY AND KNOWLEDGE WORKPLACES}

\author{
Mervi Huhtelin* and Suvi Nenonen
}

\section{Background}

The paradigm of work in the knowledge society is different from the industrial society. The change can be seen with the increasing interest in researching knowledge work from different perspectives. The term 'knowledge worker' was first coined by Peter Drucker (1959) in the discipline of management. Knowledge work occurs primarily because of mental processes rather than physical labour. Knowledge work and knowledge workers are dealing with different types of knowledge, knowledge creation and sharing processes, and knowledge management in organisations.

Organisational management includes the fields of knowledge management and organisational learning (Clegg, Kornberger, \& Pitsis, 2011), where knowledge management is linked to two distinct streams, one from psychology and one from a more technical approach to management information. Papers on learning and knowledge in organisations have been published in journals about management studies, organisation studies and organisation science (Hislop, 2013). Drucker (1959) defined knowledge workers as high-level workers who apply theoretical and analytical knowledge, acquired through formal training, to develop products and services. $\mathrm{He}$ noted that knowledge workers would be the most valuable assets of a 21 st-century organisation because of their high level of productivity and creativity. Since the term was coined, the number of knowledge workers has continued to grow as organisations move towards a collaborative workplace that gives more autonomy to their employees.

\subsection{Activities connected to knowledge creation}

Knowledge work includes several activities connected to new knowledge (Clegg et al., 2011; Dierkes, Berthoin Antal, Child, \& Nonaka, 2001; Hislop, 2013; Polanyi, 1962). One can either create new knowledge by doing research or product development, or one can acquire new knowledge by practising and gaining experience, that is, 'learning by doing'. One can also create new knowledge in knowledge workers' everyday activities.

Knowledge work tasks include knowledge acquisition, participation in shared activities and knowledge creation in various everyday activities. Questioning and criticising existing practices, analysing and modelling new solutions, experimenting and implementing solutions,

*Corresponding author: mervi.huhtelin@sykoy.fi 
evaluating and reflecting results, and consolidating new practices (Rantavuori, Engeström, \& Lipponen, 2016) are examples of knowledge work activities. Although knowledge work is perceived as high-level cognitive work, it also includes mundane tasks such as storing and retrieving information and composing and responding to e-mail (Suchman, 2000). By its very nature, knowledge work is both highly cognitive and highly social. Workers need time alone to think and develop ideas, drawing on their own memory, insight and analytical skills. They also need 'hassle-free' time for non-conscious processing that aids creativity and imagination (Claxton, 2000). Yet, for ideas and concepts to become useful to an organisation, they must be made available to others for scrutiny and further development. Thus, knowledge work also involves conversation and interaction allowing thoughts embedded in one person's mind to be externalised and accessible to others through writing, speech or graphic visualisation. This transfer happens through social networks as people encounter one another throughout the normal working day in both formal and informal settings (Allen, 1977; Backhouse \& Drew, 1992; Brown \& Duguid, 2000).

\subsection{Knowledge-sharing and creation process}

One of the most influential and widely referenced theories in the knowledge management field is Nonaka's theory of knowledge creation (Hislop, 2013), and it emphasises the importance of knowledge sharing. Knowledge sharing is a process in which individuals mutually exchange knowledge and jointly create new knowledge (De Vries, Van den Hooff, \& De Ridder, 2006). Some studies labelled knowledge sharing as 'knowledge transfer' (Maurer, Bartsch, \& Ebers, 2011; Van Wijk, Jansen, \& Lyles, 2008). Knowledge sharing has been linked to knowledge transfer from individual level to organisational level (Ipe, 2003).

In 1995 Nonaka and Takeuchi presented their theory of organisational knowledge creation. The knowledge creation process can be operationalised to the phases of 'socialisation', 'externalisation', 'combination' and 'internalisation' (SECI). The core of the knowledge creation process is the mobilisation of tacit knowledge by converting it to explicit knowledge (Nonaka \& Takeuchi, 1995). A process model of knowledge creation develops on the critical presupposition that individual knowledge is created and enlarged by means of a social interaction between tacit and explicit knowledge, where the 'tacit knowledge' refers to personal knowledge, involving an active comprehension of things known (Polanyi, 1962). This interaction is called knowledge conversion, where 'conversion' refers to the process of changing or causing something to change from one form to another.

Nonaka and Takeuchi (1995) present a SECI Model, which includes four phases:

- Socialisation: Sharing of tacit knowledge to tacit knowledge. Knowledge is passed on through practice, guidance, imitation, observation and empathising. Tacit knowledge is shared through common, hands-on experiences, for example via apprenticeship. Interaction is mainly individual, face-to-face interaction. Knowledge used is mainly experiential, skills and know-how of individuals, involving energy, passion, tension, love, care and trust.

- Externalisation: Converting tacit knowledge to explicit knowledge. This is deemed as a difficult and often important conversion mechanism. Explicit knowledge is articulated through images, symbols and language. Concept creation in new product development is linked in this phase. Tacit knowledge is codified into documents, manuals, etc. so that it can spread more easily throughout the organisation. Since tacit knowledge can be virtually impossible to codify, the extent of this knowledge conversion mechanism is debatable. The use of metaphor is cited as an important externalisation mechanism. Interaction is mainly collective, 
peer-to-peer and face-to-face interaction. Knowledge used in mainly conceptual and can include the creation of product concepts, design and brand equity.

- Combination: Combining explicit knowledge into more complex and systematic sets of explicit knowledge. This phase of knowledge creation process is seen to be the simplest one; codified knowledge sources (e.g. documents) are combined to create new systemised and packaged explicit knowledge via collective, group-to-group kind of virtual and collaborative interaction. Knowledge used in this phase are mainly documents, manuals, database, patents and product specifications.

- Internalisation: Converting explicit knowledge to tacit knowledge. Tacit knowledge is routinised and embedded in actions and practices. Internalisation is closely related to learning by doing. As explicit sources are used and learned, the knowledge is internalised, modifying the user's existing tacit knowledge including reflection through action. 'Trying to understand' is vital in this phase. To conduct experiments and share results with the entire department is important. Interaction is individual or virtual or it takes place on site, sharing both time and space. Knowledge used in this phase are mainly know-how in daily operations, organisational routines and culture, practical knowledge and mass production.

In this model, knowledge is continuously converted and created as individual practice, collaboration, interaction and learning. The process should be seen as a continuous, dynamic swirl of knowledge rather than a static model. It is basically a visual representation of overlapping, continuous processes that take place - or should take place - in an organisation. This model is based on the theory that knowledge is created by individuals and then transmitted to the organisation (Finley \& Sathe, 2013; Rai, 2011).

\subsection{Workplace as a foundation for knowledge-sharing and creation process}

New approaches towards workplace and its ability to support knowledge creation processes started in the early 2000s (Danivska, 2018). The research is often based on Nonaka's concept ' $\mathrm{Ba}$ '. $\mathrm{Ba}$ is the shared context and the place where knowledge is created. It can be physical (e.g. office, dispersed business space), virtual (e.g. email, teleconference), mental (e.g. shared experiences, ideas, ideals) or any combination of them. Ba provides a platform for advancing individual and/or collective knowledge. There are four types of $\mathrm{Ba}$ that correspond to the four phases of the SECI model, each Ba especially suited to each of the four knowledge conversion phases. Next is a description of different Bas (adapted from Huhtelin \& Nenonen, 2015; Nenonen, 2005; Nonaka \& Konno, 1998; Nonaka \& Takeuchi, 1995; Nonaka, Toyama, \& Byosière, 2001):

'Originating Ba', supporting Socialisation: Originating Ba supports individual face-to-face interaction, which is the only way to capture the full range of physical senses and psychoemotional reactions, such as ease or discomfort, which are important elements in sharing tacit knowledge. Individuals share feelings, emotions, experiences and mental models. From Originating $\mathrm{Ba}$ emerge care, love, trust and commitment, which form the basis for knowledge conversion among individuals. Informal social meetings with competitors outside the firm or wandering inside the firm are used to gather knowledge needed in business development. Peers understand expertise through practice and demonstrations by a master.

'Dialoguing $B a$ ', supporting Externalisation: Dialoguing $\mathrm{Ba}$ is defined by collective peer-topeer and face-to-face interaction with conceptual knowledge, product concepts and 
design. Individuals' mental models and skills are shared, converted into common terms and articulated as concepts. The individual can profit from the creativity-producing synthesis of rationality and intuition. Metaphor, metonymy and synecdoche are used when converting tacit knowledge to explicit knowledge.

'Systemising Ba', supporting Combination: Systemising $\mathrm{Ba}$ is defined by collective and virtual interactions, rather than real time and space, so it is also called 'cyber Ba'. It is where new systemic, explicit knowledge is created through a combination of various elements of explicit knowledge. Interaction is collective, group-to-group in virtual platforms supporting access to databases, patents and product specifications. It is supported in a collaborative environment utilising information technology, such as online networks, documentation and databanks. Clear, articulated language is used.

'Exercising Ba' supporting Internalisation: The place where the conversion of explicit knowledge into tacit knowledge is facilitated. Exercising $\mathrm{Ba}$ is defined by individual, onsite or virtual interaction. Expertise in daily operations and practical knowledge are used, and organisational routines and culture are present for individuals to embody explicit knowledge that is communicated through virtual media, such as written manuals. Continuous learning and self-refinement through on-the-job training are stressed in order to communicate knowledge. Exercising Ba synthesises the transcendence and reflection through action. The internalisation of knowledge is constantly enhanced, using explicit knowledge in real life or in simulated applications.

Figure 22.1 shows the connection of each phase of knowledge creation process and each $\mathrm{Ba}$ supporting that phase.

Nevertheless, critique has also occurred (Amin \& Cohendet, 2004; Gourlay, 2006; Tsoukas, 2005). Amin and Cohendet (2004) have pointed out that Nonaka's understanding of Ba and the descriptions of four relational spaces are simplified. Additionally, scholars question the sequential steps of the four Bas in the knowledge conversion process and find Nonaka's view on the relational spaces restricting: each $\mathrm{Ba}$ is capable of doing more than what Nonaka's model (Nonaka \& Konno, 1998) permits. Additionally, the SECI model's universal applicability (Hislop, 2013)

\begin{tabular}{|c|c|c|c|}
\hline $\begin{array}{l}\text { Sharing of tacit } \\
\text { knowledge to tacit } \\
\text { knowledge }\end{array}$ & $\begin{array}{l}\text { Knowledge creation phase: "Socialisation" } \\
\text { Empathising: Tacit knowledge shared through } \\
\text { common, hands-on experiences, apprenticeship. }\end{array}$ & $\begin{array}{l}\text { Knowledge creation phase: "Externalisation" } \\
\text { Articulating: Explicit knowledge articulated } \\
\text { through images, symbols, and language. Concept } \\
\text { creation in new product development. }\end{array}$ & $\begin{array}{l}\text { Converting tacit } \\
\text { knowledge to } \\
\text { explicit knowledge }\end{array}$ \\
\hline $\begin{array}{l}\text { Individual } \\
\text { face-to-face } \\
\text { interaction } \\
\text { with skills and } \\
\text { know-how }\end{array}$ & $\begin{array}{l}\quad \text { "Originating Ba" } \\
\text { Ba supports individuals sharing feelings, emotions, } \\
\text { experiences, and mental models. Care, love, trust, } \\
\text { and commitments emerges. }\end{array}$ & $\begin{array}{l}\text { "Dialoguing Ba" } \\
\text { Ba supports reflection and dialogue amongst } \\
\text { participants. Mental models and skills possessed by } \\
\text { individuals are shared, converted into common } \\
\text { terms, and articulated as concepts. }\end{array}$ & $\begin{array}{l}\text { Collective, peer-to- } \\
\text { peer and face-to- } \\
\text { face interaction } \\
\text { with conceptual } \\
\text { knowledge }\end{array}$ \\
\hline $\begin{array}{l}\text { Individual, on site } \\
\text { or virtual } \\
\text { interaction with } \\
\text { knowhow and } \\
\text { practical knowledge }\end{array}$ & $\begin{array}{l}\text { "Exercising Ba" } \\
\text { Continuous learning through on-the-job training or } \\
\text { active participation are stressed in order to } \\
\text { communicate knowledge, with know-how, practical } \\
\text { knowledge, organizational routines and culture. }\end{array}$ & $\begin{array}{l}\text { "Systemising Ba" } \\
\text { New systemic, explicit knowledge is created } \\
\text { through a combination of various elements of } \\
\text { explicit knowledge with databases, patents and } \\
\text { product specifications. }\end{array}$ & $\begin{array}{l}\text { Collective, group- } \\
\text { to-group, virtual } \\
\text { interaction for } \\
\text { collaboration with } \\
\text { explicit knowledge }\end{array}$ \\
\hline
\end{tabular}

Figure 22.1 SECI model and Ba (adapted from Nonaka \& Takeuchi, 1995; Nonaka \& Konno, 1998; Huhtelin \& Nenonen, 2015) 
has been questioned and studied (Magnier-Watanabe \& Benton, 2013). However, Nonaka and Krogh (2009) have responded to the criticism by clarifying that their theory is focused on the knowledge creation used by organisations, where beliefs are true to the extent that they can be justified by the individual organisational member at certain moments and by using various mental models. They emphasised that the SECI model is not based on the assumption that all tacit knowledge can be transferred to explicit knowledge. Additionally, they clarified the tacit explicit distinction along the continuum, yet emphasised that it is still important to distinguish tacit knowledge from explicit knowledge in the knowledge creation process.

Overall, the research has shown the importance of the physical work environment as a mechanism that stimulates knowledge sharing within organisations (Chevez \& Aznavoorian, 2014). The physical infrastructure (i.e. design of the building, spaces and facilities) is also determined as one of the main dimensions of knowledge management infrastructure (Becerra-Fernandez \& Sabherwal, 2010).

\section{Applicability to workplace studies}

When seeking comprehension of workplace management research, knowledge creation theory and the concept $\mathrm{Ba}$ are useful frameworks. One can understand the knowledge work activities and diverse requirements for workplaces supporting those activities. In this chapter, first a study connected to the process of knowledge creation is presented, focusing on the knowledgesharing behaviour in connection with the places. This is followed by a description of two studies that provide insights into how the concept $\mathrm{Ba}$ can be used by analysing different phases of knowledge creation. Finally, the study about the nature of workplace for knowledge creation is presented, with two use cases. The last two studies apply the study of the nature of the workplace for knowledge creation as a framework to support the analysis of the data collected about the requirements for workplaces.

\subsection{Knowledge creation process and knowledge-sharing behaviour in workplaces}

Weijs-Perrée (2019) studied the influence of the physical work environment on business centre users' propensity to share different types of knowledge. She based her study on Nonaka's knowledge creation process (SECI model) and the different types of places (Bas) for knowledge sharing. She analysed the different types of shared knowledge and the places where it was shared, through face-to-face interaction patterns. Based on her results, tacit knowledge is shared more frequently during discussions/debates, during formal meetings and when receiving or giving advice. Weijs-Perrée's study showed relations between the physical work environment, knowledge sharing and networking behaviour. Other studies, for example by Weijs-Perrée, Buck, Appel-Meulenbroek, and Arentze (2019), have been conducted to understand where people engage in face-to-face interaction.

\subsection{Knowledge co-creation and knowledge workplace}

Huhtelin and Nenonen (2015) have studied what kinds of places support knowledge sharing and knowledge co-creation in university-industry collaboration, describing the requirements for the place. It turned out that Originating $\mathrm{Ba}$, which supports informal interaction, is a place where tacit knowledge can be co-created (Huhtelin \& Nenonen, 2015). They state that the place supporting the beginning of the university-industry collaboration should be one in which 
individuals share feelings, emotions, experiences and mental models. Originating Ba should be open to external connections, supporting networking and being informal as a nature as Nenonen (2005) describes in her research. Additionally, Dialoguing Ba is also important for knowledge co-creation in university-industry collaboration (Huhtelin \& Nenonen, 2015).

Another study focusing on knowledge sharing and knowledge co-creation in university industry collaboration is focused on business incubators. This study investigated the sharing of the knowledge developed in a university in the context of incubation centres (Strid, 2006). Both studies aim to understand the requirements supporting collaboration between university and industry by using the concept Ba. Even though the result was not completely aligned, both studies indicated that two Bas - Originating $\mathrm{Ba}$ and Dialoguing $\mathrm{Ba}$ - are important when facilitating knowledge sharing between universities and companies. The university-industry collaboration has been approached in the context of both incubation centres and collaboration platforms among more established industry actors.

\subsection{The nature of the workplace for each phase of knowledge creation}

Nenonen has studied the nature of the workplace, which is supporting all phases of the knowledge creation as a physical, social and virtual environment (Nenonen, 2005). The explorative research states that we have been designing workplaces for explicit knowledge creation, but the places for tacit knowledge creation are not taken into account evenly. She presents four knowledge workplace concepts: 'connective place', 'structural place', 'formal place' and 'reflective place'. Each of them is different by atmosphere and also represent different kinds of knowledge work processes. Figure 22.2 illustrates how the concepts are integrated into the knowledge process circle. The following list, adapted from Nenonen (2005) and Huhtelin and Nenonen (2016, 2019), describes the concepts:

The connective place is an environment that supports the exchange of tacit knowledge in the socialisation phase of knowledge creation. The place is open to the external world, easy

\begin{tabular}{|c|c|c|c|}
\hline $\begin{array}{l}\text { Sharing of tacit } \\
\text { knowledge to tacit } \\
\text { knowledge }\end{array}$ & $\begin{array}{l}\text { "Socialisation" / "Originating Ba" } \\
\text { Tacit knowledge is shared through common, hands-on } \\
\text { experiences, apprenticeship. Individual face-to-face } \\
\text { interaction with skills, passion, energy, know-how. }\end{array}$ & $\begin{array}{l}\text { "Externalisation" / "Dialoguing Ba" } \\
\text { Explicit knowledge articulated through images, symbols, } \\
\text { and language. Collective, peer-to-peer, face-to-face } \\
\text { interaction with conceptual knowledge. }\end{array}$ & $\begin{array}{l}\text { Converting tacit } \\
\text { knowledge to explicit } \\
\text { knowledge }\end{array}$ \\
\hline $\begin{array}{l}\text { Place is open for } \\
\text { external world, } \\
\text { supporting } \\
\text { collaboration and } \\
\text { informal interaction }\end{array}$ & $\begin{array}{l}\text { The connective place } \\
\text { The nature of the workplace is open and welcoming. It is } \\
\text { easy to access and approach. The atmosphere is warm, } \\
\text { inspiring, cosy, and there is a sense of hospitality. Entrance } \\
\text { halls or marketplaces are an example of the connective } \\
\text { place. }\end{array}$ & $\begin{array}{l}\text { The structural place } \\
\text { The nature of the workplace is functional, dynamic, } \\
\text { organised and it might be conservative. The clear structure } \\
\text { and the social atmosphere helps concentration to the task } \\
\text { and collaboration. The formal meeting room and the } \\
\text { traditional rooms for executives are examples of the } \\
\text { structural place. }\end{array}$ & $\begin{array}{l}\text { Place is open for } \\
\text { external world, } \\
\text { dedicated to meetings } \\
\text { and task-oriented } \\
\text { formal working }\end{array}$ \\
\hline $\begin{array}{l}\text { Closed space for } \\
\text { privacy, peaceful } \\
\text { reflecting, sharing of } \\
\text { experiences and } \\
\text { informal interaction }\end{array}$ & $\begin{array}{l}\text { The reflective place } \\
\text { The nature of the workplace is cosy, peaceful and a shared } \\
\text { place. The dynamic atmosphere is based on a sense of the } \\
\text { workplace belonging to everyone. An example of the } \\
\text { reflective place is a coffee area or informal meeting place } \\
\text { with the feeling of a living room. }\end{array}$ & $\begin{array}{l}\text { The formal place } \\
\text { The place is offering privacy, silence and concentration. } \\
\text { The office layout with a chain of individual, cell offices, is } \\
\text { an example of the formal place. The workstation for } \\
\text { individual work without disturbance is also an example. }\end{array}$ & $\begin{array}{l}\text { Closed space for } \\
\text { concentration, privacy } \\
\text { and task-oriented } \\
\text { formal work }\end{array}$ \\
\hline $\begin{array}{l}\text { Converting explicit } \\
\text { knowledge to tacit } \\
\text { knowledge }\end{array}$ & $\begin{array}{l}\text { "Internalisation" / "Exercising Ba" } \\
\text { Embodying explicit knowledge into tacit knowledge. } \\
\text { Individual, on site or virtual interaction with e.g. know- } \\
\text { how, practical knowledge. }\end{array}$ & $\begin{array}{l}\text { "Combination" / "Systemising Ba or Cyber Ba" } \\
\text { Converting explicit knowledge into more systemised } \\
\text { explicit knowledge. Collective, group-to-group, virtual } \\
\text { interaction for collaboration with e.g. databases, } \\
\text { documents. }\end{array}$ & $\begin{array}{l}\text { Combining explicit } \\
\text { knowledge to explicit } \\
\text { knowledge }\end{array}$ \\
\hline
\end{tabular}

Figure 22.2 Nature of the workplace (adapted from Nenonen, 2005; Huhtelin \& Nenonen, 2016, 2019) 
to access and approach, and supports collaboration and informal interaction. It is a platform for new, fresh tacit knowledge and the sharing of it with people inside and outside the organisation. The atmosphere is warm and welcoming, inspiring and cosy, and there is a sense of hospitality. The ownership belongs to all people. Entrance halls or marketplaces are an example of the connective place.

The structural place is an environment that supports the conversion of tacit knowledge into explicit knowledge (the externalisation phase). The place is open to the external world, dedicated to meetings and collaboration, and supports task-oriented formal working. The functionality of the place is high. The dynamic atmosphere of the place might be conservative and dedicated to task performance, like that of a formal meeting room and the traditional rooms for executives.

The formal place is an environment that supports the analysis of explicit knowledge in the combination phase of knowledge creation. This place is a closed space; it is more for individual and private work performances and supports concentration and task orientation. The atmosphere can be tense, and the place is difficult to approach. The virtual workplace is dedicated for information, and it is faceless. The use of it is based on norms and rules, which are not transparent. The office layout, with a chain of individual, cell offices, is an example of the formal place. The workstation for individual work without disturbance is also an example.

The reflective place is an environment that supports the sharing of explicit knowledge and transforming it into tacit knowledge (the internalisation phase). This place is a closed and cosy space for privacy, peaceful reflecting, sharing of experiences and informal interaction. Internal privacy is respected while the dynamic atmosphere is based on a sense of the workplace belonging to everyone. The place empowers reflection and relaxation. The virtual workplace facilitates the sharing of information and the transformation of it into new knowledge. An example of the reflective place is a coffee area or informal meeting place with soft couches and the feeling of a living room. The virtual workplace facilitates the sharing of information and the transformation of it for knowledge.

\subsection{Knowledge creation phases as a framework in studies of academic workplaces}

Huhtelin and Nenonen (2016, 2019) have studied places supporting knowledge work and knowledge creation in the university context. They were interested in understanding the differences in knowledge work in terms of demography or different disciplines. They used the data gathered via a survey questionnaire and analysed it with the framework connected to the knowledge creation phases. They found that older researchers also required external connections to be able to connect their knowledge to other fields of research (Huhtelin \& Nenonen, 2016). In their next study (Huhtelin \& Nenonen, 2019) the findings indicated that researchers from different disciplines have different requirements for the place supporting each phase of knowledge creation. That result was aligned to the description of the nature of different disciplines. The framework that was used clarified the analysing process of the data in both studies.

\section{Methodology/research approach}

The approach used in the presented research projects is mostly qualitative, however some quantitative approaches have also been chosen. The descriptive and explorative nature of the research is 
common. Methods include case study, literature reviews and interviews as well as surveys. Some papers are published with qualitative data based on content analysis.

The focus in different studies has varied also in terms of sample. Knowledge workers from organisations, business incubators and business-centre-type environments as well as university campuses were included. The organisational knowledge creation process (SECI model) and knowledge creation places (concept $\mathrm{Ba}$ ) have proven to be useful when seeking to understand the requirements for workplaces, in the context of both universities and private sector organisations. The research is also inspired by the user-centric approach - the results provide contributions both to practice and to research by understanding the demand of knowledge workers and knowledge creation processes.

There are some research gaps which knowledge creation theories can overcome. Knowledge work and its requirements are easier to analyse by following the knowledge creation process phases. However, the physical work environment is only one aspect in facilitating the knowledge creation process, as much of the knowledge creation takes place on digital and virtual platforms. The integration of these two entities is still lacking in research. Additionally, how space is used can be an important determinant. Office etiquette or the lack of it should also be studied in connection with physical and digital work environments. One also needs to integrate the servicescape with the supporting and required factors for supporting knowledge work.

\section{Limitations}

Even though the knowledge creation theory provides a possibility to increase understanding of knowledge work, it has some limitations. The most challenging limitation is the cultural aspect. The Japanese concept $\mathrm{Ba}$ is descriptive. The ideas of transcending boundaries of oneself and knowledge conversion can be interpreted differently in European or in US contexts (Magnier-Watanabe \& Benton, 2013). This limitation is discussed also in studies by Senoo, Magnier-Watanabe, and Salmador (2007).

Additionally, the theory can be interpreted differently based on the research tradition of different disciplines. The knowledge creation theory with four different phases (SECI) as well as the Bas are most likely understood, defined and investigated based on interpretation of the background of the researcher(s). The frameworks are theoretical descriptions of a real-world phenomenon and hence are not capable of capturing all the elements and nuances of the organisational knowledge creation practices. However, these limitations challenge researchers to work more closely in transdisciplinary teams. The comparison and integration of different perspectives will validate the interpretation and provide richer results.

\section{Theory relevance to practice}

The increased understanding of the knowledge creation process can help to develop organisational practices and processes. It provides a tool for designers to capture user-centred requirements for knowledge workplaces, for example for activity-based work environments. It provides a way to identify the work based on explicit knowledge as well as the work based on tacit knowledge. All these work activities require different kinds of environments - physical, digital or even mental realities. This means that new kinds of space typologies for the design of offices is needed.

Depending on the main goal of an organisation, its knowledge workers' work profiles differ, some being mainly focused in combining explicit knowledge, some having greater aspiration in enhancing personal skills and know-how, connected to tacit knowledge. For example, the work of an accountant consists primarily of combining explicit knowledge to existing explicit 
knowledge, and the work of a director in an advertising agency consists primarily of socialisation with clients, trying to understand their profession, and tacit knowledge embedded in their experience about their business. Further, when the need to be able to socialise and understand tacit knowledge of the clients has been identified, practitioners can apply existing research about places that enhance networking behaviour and face-to-face interaction known to facilitate tacit knowledge sharing (Weijs-Perrée, 2019; Weijs-Perrée et al., 2019).

The digital work environment and its use can also be more thoroughly understood by using the knowledge creation process phases and characteristics of spaces as the reflection point: how we can collaborate and share tacit knowledge and how we can focus on explicit knowledge alone or together in digital platforms and spaces. The hybrid working environments include both physical and digital solutions. The more integrated they are, the more potential is provided for the knowledge workers of today and the future.

\section{Further reading}

- Nonaka, I., \& Konno, N. (1998). The concept of "Ba": Building foundation for knowledge creation. California Management Review, 40(3), 40-54. Retrieved from www.semanticscholar. org/paper/The-Concept-of-\%22-Ba-\%22-\%3A-BUILDING-A-FO-Nonaka-Konn/b6b 340a3186c28646b8518f7ae6d82543aa26ea2?p2df

- $\quad$ Petrulaitiene, V., Rytkönen, E., Nenonen, S., \& Jylhä, T. (2017). Towards responsive work places - Identifying service paths for time-and place independent work. Journal of Corporate Real Estate, 19(3), 144-156. https://doi.org/10.1108/JCRE-10-2016-0034

- Senoo, D., Magnier-Watanabe, R., \& Salmador, M. P. (2007). Workplace reformation, active $\mathrm{Ba}$ and knowledge creation: From a conceptual to a practical framework. European Journal of Innovation Management, 10(3), 296-315. https://doi.org/10.1108/14601060710776725

\section{References}

Allen, T. J. (1977). Managing the flow of technology: Technology transfer and the dissemination of technical information within RED organizations. Cambridge, MA: MIT Press.

Amin, A., \& Cohendet, P. (2004). Architectures of knowledge: Firms, capabilities, and communities. New York: Oxford University Press.

Backhouse, A., \& Drew, P. (1992). The design implications of social interaction in a workplace setting. Environment and Planning B Planning and Design, 19, 573-584. https://doi.org/10.1068/b190573

Becerra-Fernandez, I., \& Sabherwal, R. (2010). Knowledge management: Systems and processes. Armonk, NY: M.E. Sharpe.

Brown, J. S., \& Duguid, P. (2000). The social life of information. Boston, MA: Harvard Business School Press.

Chevez, A., \& Aznavoorian, L. (2014). Space as a knowledge management tool. Work \& Place, 4, 11-14. Retrieved from https://workandplace.com/space-as-a-knowledge-management-tool/

Claxton, G. (2000). Hare brain, tortoise mind: How intelligence increases when you think less. New York: HarperCollins.

Clegg, S. R., Kornberger, M., \& Pitsis, T. S. (2011). Managing E organizations: An introduction to theory and practice (3rd ed.). London: SAGE Publications.

Danivska (Petrulaitiene), V. (2018). From walls to experiences workplace transformation from physical office space to 'workplace-w s-a-service' model [Doctoral dissertation]. Aalto University publication series doctoral dissertations $(158 / 2018)$.

De Vries, R. E., Van den Hooff, B., \& De Ridder, J. A. (2006). Explaining knowledge sharing: The role of team communication styles, job satisfaction, and performance beliefs. Communication Research, 33(2), 115-135. https://doi.org/10.1177/0093650205285366

Dierkes, M., Berthoin Antal, A., Child, J., \& Nonaka, I. (2001). Handbook of organizational learning and knowledge. Oxford: Oxford University Press.

Drucker, P. (1959). Landmarks of tomorrow. New York: Harper. 
Finley, D., \& Sathe, V. (2013). Nonaka's SECI framework: Case study evidence and an extension. Kindai Management Review, 1, 59-68. Retrieved from www.semanticscholar.org/paper/Nonaka\%E2\%80\%99sSECI-Framework\%3A-Case-Study-Evidence-and-an-FinleySath\%C3\%A9/1dfcd378df22dc40c53d2f6 $30903 \mathrm{e} 423 \mathrm{be} 8 \mathrm{e} 6 \mathrm{c} 41$

Gourlay, S. (2006). Conceptualizing knowledge creation: A critique of Nonaka's theory. Journal of Management Studies, 43(7), 1415-1436. https://doi.org/10.1111/j.1467-6486.2006.00637.x

Hislop, D. (2013). Knowledge management in organizations: A critical introduction (3rd ed.). Oxford: Oxford University Press.

Huhtelin, M., \& Nenonen, S. (2015). A co-creation centre for university-industry collaboration: A framework for concept development. Elsevier Procedia Economics and Finance, 21, 137-145. https://doi. org/10.1016/S2212-5671(15)00160-4

Huhtelin, M., \& Nenonen, S. (2016). The workplace for researchers - Enhancing concentration and face-to-face interaction. In K. Kähkönen \& M. Keinänen (Eds.), Proceedings of the CIB world building congress 2016: Volume I - Creating built environments of new opportunities (pp. 753-764). Tampere University of Technology. Department of Civil Engineering. Retrieved from http://urn.fi/ URN:ISBN:978-952-15-3741-7

Huhtelin, M., \& Nenonen, S. (2019). The workplaces of researchers in different disciplines. Journal of Corporate Real Estate, 21(1), 36-54. https://doi.org/10.1108/JCRE-11-2017-0043

Ipe, M. (2003). Knowledge sharing in organizations: A conceptual framework. Human Resource Development Review, 2(4), 337-359. https://doi.org/10.1177/1534484303257985

Magnier-Watanabe, R., \& Benton, C. (2013). Enablers of knowledge management across borders: A structural approach. International Journal of Innovation and Technology Management, 10(4), 1350012-1-135001221. https://doi.org/10.1142/S0219877013500120

Maurer, I., Bartsch, V., \& Ebers, M. (2011). The value of intra-organizational social capital: How it fosters knowledge transfer, innovation performance, and growth. Organization Studies, 32(2), 157-185. https://doi.org/10.1177/0170840610394301

Nenonen, S. (2005). The nature of the workplace for knowledge creation [Doctoral dissertation] Retrieved from Turku University of Applied Sciences, ISBN: 9525596338.

Nonaka, I., \& Konno, N. (1998). The concept of "Ba": Building foundation for knowledge creation. California Management Review, 40(3), 40-54. Retrieved from www.semanticscholar.org/paper/TheConcept-of-\%22-Ba-\%22-\%3A-BUILDING-A-FO-Nonaka-Konn/b6b340a3186c28646b8518f7ae6 d82543aa26ea2?p2df

Nonaka, I., \& Tackeuchi, H. (1995). The knowledge-creating company. New York: Oxford University Press.

Nonaka, I., Toyama, R., \& Byosière, P. (2001). A theory of organizational knowledge creation: Understanding the dynamic process of creating knowledge. In M. Dierkes, A. Berthoin Antal, J. Child, \& I. Nonaka (Eds.), Handbook of organizational learning and knowledge (pp. 491-517). Oxford: Oxford University Press.

Nonaka, I., \& von Krogh, G. (2009). Tacit knowledge and knowledge conversion: Controversy and advancement in organizational knowledge creation theory. Organization Science, 20(3), 635-652. https://doi.org/10.1287/orsc. 1080.0412

Polanyi, M. (1962). Personal knowledge: Towards a post-critical philosophy. London: Routledge.

Rai, R. K. (2011). Knowledge management and organizational culture: A theoretical integrative framework. Journal of Knowledge Management, 15(5), 779-801. https://doi.org/10.1108/13673271111174320

Rantavuori, J., Engeström, Y., \& Lipponen, L. (2016). Learning actions, objects and types of interaction: A methodological analysis of expansive learning among pre-service teachers. Frontline Learning Research, 4(3), 1-27. https://doi.org/10.14786/flr.v4i3.174

Senoo, D., Magnier-Watanabe, R., \& Salmador, M. P. (2007). Workplace reformation, active Ba and knowledge creation: From a conceptual to a practical framework. European Journal of Innovation Management, 10(3), 296-315. https://doi.org/10.1108/14601060710776725

Strid, M. (2006). Rum för entreprenörskap. En studie av universitetsbaserade företagsinku-batorer $i$ Västsverige [Doctoral dissertation]. Chalmers University of Technology, Architecture and Civil Engineering: 2006:02 New series $\mathrm{Nr} 2443$.

Suchman, L. (2000). Making a case: Knowledge and routine work in document production. In P. Luff, J. Hindmarsh, \& C. Heath (Eds.), Workplace studies: Recovering work practice and informing system design (pp. 29-45). Cambridge: Cambridge University Press.

Tsoukas, H. (2005). Do we really understand tacit knowledge? In Handbook of organizational learning and knowledge. Blackwell. Retrieved from www.researchgate.net/publication/2528222_Do_We_Really_ Understand_Tacit_Knowledge 
Van Wijk, R., Jansen, J. P., \& Lyles, M. A. (2008). Inter- and intra-organizational knowledge transfer: A meta-analytic review and assessment of its antecedents and consequences. Journal of Management Studies, 45, 815-838. https://doi.org/10.1111/j.1467-6486.2008.00771.x

Weijs-Perrée, M. (2019). The users'value of business center concepts for knowledge sharing and networking behavior within and between organizations [Doctoral dissertation]. Eindhoven University of Technology urn:nbn:nl:ui:25-2ed6fc49-56cb-499c-826b-ea0bec676b66

Weijs-Perrée, M., Buck, L., Appel-Meulenbroek, R., \& Arentze, T. (2019). Location choices of face-toface interactions in academic buildings: An experience sampling approach. Ergonomics, 62(12), 14991514. https://doi.org/10.1080/00140139.2019.1660419 